\title{
Assessment of serum vitamin $D$ levels in Egyptian children with beta-thalassemia major
}

\author{
Ghada Saad Abdelmotaleb', Ola Galal Behairy ${ }^{1 *}$ (D), Khalid Eid Abd El Azim², Dalia Mohamed Abd El-Hassib³ and \\ Tasbeh Mohamed Hemeda ${ }^{4}$
}

\begin{abstract}
Background: Beta-thalassemia major patients are at increased risk of complications including endocrinopathies and bone disease due to iron overload. So, this study aimed to assess the growth parameters, serum levels of $25-\mathrm{OH}-$ vitamin $\mathrm{D}$, calcium, and phosphorous in children with beta-thalassemia major. This was a case-control study that included 55 children with beta-thalassemia major compared with 30 sex-and age-matched healthy children that served as a control group. All enrolled children were subjected to full history taking, clinical examination including anthropometric measurements, and laboratory investigations including complete blood count, serum ferritin, levels of serum calcium, phosphorus, and 25-OH-vitamin D.
\end{abstract}

Results: Body mass index was statistically significantly lower in the thalassemic group $(P<0.001)$. It was observed that vitamin $D$ levels were significantly lower in thalassemic patients than in controls $(P$ value $<.0001)$. The mean serum $25-\mathrm{OH}$-vitamin D levels were $19.84 \pm 5.79 \mathrm{ng} / \mathrm{ml}$ and $44.98 \pm 5.77 \mathrm{ng} / \mathrm{ml}$, respectively; 22 cases (40\%) had insufficient vitamin D, and 5 cases (9\%) had deficient vitamin D. Regarding serum calcium and phosphorous, there was no significant difference between the thalassemic and control groups.

Conclusion: Children with beta-thalassemia major had low body mass index and metabolic abnormality in the form of lower serum levels of vitamin D that signify the importance of therapeutic interventions.

Keywords: Calcium, Children, Phosphorous, Beta-thalassemia major, 25-OH-vitamin D

\section{Background}

Thalassemia is the most relevant genetic disorder in humans being found in nearly every nation and mostly in the Mediterranean regions, hence the name [1]. It varies clinically from silent heterogeneous thalassemia minor to significant transfusion-dependent thalassemia major [2]. In Egypt, $\beta$-thalassemia represents a significant public health issue. It has been estimated that out of 1.5 million live births, 1000 kids are born annually with significant thalassemia major. The carrier rate in Egypt was recorded to be between 9 and 10\% [3] due to the elevated consanguineous marriage, which might

\footnotetext{
* Correspondence: olaped99@yahoo.com

${ }^{1}$ Pediatrics Department, Faculty of Medicine, Benha University, Benha, Egypt Full list of author information is available at the end of the article
}

reach $35.3 \%$, that helps accumulating deleterious genes in families [4].

Bone disease from thalassemia has emerged as a significant challenge and a prominent cause of morbidity in both sexes. Thalassemic patients have numerous bone illnesses, including bone deformities, bone pain, rickets, scoliosis, pathological fractures, osteopenia, and osteoporosis [5]. The etiology of thalassemia-associated bone diseases is complex multifactorial including hormonal deficiency, owing in particular to hypogonadism and hypoparathyroidism secondary to hemosiderosis, marrow expansion, iron overload, and desferrioxamine toxicity, that affect bone metabolism seriously [6, 7].

Vitamin D is critical for calcium homeostasis and mineralization of the skeleton [8]. Its deficiency leads to 
reduced bone mineralization and loss of cortical bone, resulting in osteopenia osteoporosis syndrome (OOS) [9]. Here, we aimed to assess the growth parameters, vitamin $\mathrm{D}$, calcium, and phosphorus status in children with beta-thalassemia major.

\section{Methods}

This case-control study took place in the outpatient hematology clinic, between December 2016 and December 2018. The study was conducted on 85 Egyptian children divided into group I (beta-thalassemia major group) that included 55 children; their diagnosis was based on standard criteria, including $\mathrm{Hb}$ electrophoresis, regularly transfused with packed RBCs, and regularly receiving chelation therapy [10]. The exclusion criteria included other chronic hemolytic anemia, feeding difficulties or malnutrition diseases, and children who have other chronic diseases (cardiac diseases, chest diseases, renal disease, etc.). Group II included 30 age- and sex-matched healthy children as the control group collected from the general population. All cases and control were not receiving vitamin $\mathrm{D}$-containing preparations. The current study was approved by the medical research ethical committee of the faculty of medicine. All subjects were informed about the procedures and the aim of the study, and an informed written consent was obtained from the parents or caregivers of the enrolled children.

\section{Methods}

Enrolled children were subjected to the following:

- Thorough history taking with stress on age at first transfusion, type, and duration of chelation; compliance to chelation therapy; and history of splenectomy.

- Clinical examination, including clinical evidence of complications of iron overload and skin hemosiderosis and anthropometric measurements of patients and controls including age, sex, weight, height, and $Z$-score were recorded. Weight was measured in kilograms (to the nearest $100 \mathrm{~g}$ ) using an electronic digital scale, and its accuracy was periodically verified using reference weights. Height was measured in centimeters (measured to the nearest millimeter); children were measured on scales with height gauges, the subject standing with the back against the gauge and the feet on the weighing platform. Software program combines the raw data on the variables (age, sex, length, and weight) to compute a nutritional status index such as $Z$-score, weight-for-height, weight-for-age, and height-for-age [11]. BMI (weight/height [2]) was calculated for both boys and girls at different ages and was compared with standardized percentile curves of BMI for children and adolescents [12]. In the study, less than the 10th percentile of BMI was considered as underweight

- Laboratory investigations.

Blood sample: venous blood, $5 \mathrm{ml}$, was drawn under complete aseptic conditions and distributed as follows:

1. Whole blood, $1 \mathrm{ml}$, was taken in an EDTA vacutainer and mixed gently. This sample was used to measure complete blood count, which was performed by an automated hematology system (by SysmexKX-21 N; Sysmex Corporation, America, Inc., Mundelein, IL, USA) [13].

2. Samples of blood, $4 \mathrm{ml}$, were taken in plain test tubes without anticoagulants. The samples were allowed to clot for $30 \mathrm{~min}$ at room temperature and then centrifuged for $15 \mathrm{~min}$ at $1000 \times \mathrm{g}$. The serum was removed, aliquoted, and stored at $\leq-20{ }^{\circ} \mathrm{C}$ until used. The separated serum was used for the following:

(a) Serum ferritin ( $\mathrm{ng} / \mathrm{ml}$ ) was estimated by enzyme-linked immunosorbent assay (ELISA; R\&D Systems, Minneapolis, MN, USA). The normal range for ferritin is $20-280 \mathrm{ng} / \mathrm{ml}$ for males and $10-140 \mathrm{ng} / \mathrm{ml}$ for females

(b) Serum level of calcium $(\mathrm{mg} / \mathrm{dl})$ was estimated using BIOSYSTEM A15 using kits supplied (Spectrum, Germany) with lot number CALC013017, reference number: $226001(2 \times$ $30 \mathrm{ml}$ ).

(c) Serum level of phosphorus $(\mathrm{mg} / \mathrm{dl})$ was estimated using by BIOSYSTEM A15 using kits supplied (Spectrum, Germany) with lot number PHOK0101017, reference number:294001 (4x $25 \mathrm{ml}$ )

(d) Alkaline phosphatase and liver function tests [aspartate aminotransferase (AST), alanine aminotransferase (ALT)] were estimated using BIOSYSTEM A15 auto-analyzer by appropriate chemical principles. Hepatitis B surface antigen (HBsAg) and anti-HCV antibody (HCV-Ab) by enzyme-linked immunosorbent assay (ELISA) were done, and confirmation of HCV and HBV infection was done by using PCR (Biokit, Spain) as these data collected from medical records of the patients.

(e) Serum levels of 25-hydroxyvitamin D by enzyme-linked immunosorbent assay (ELISA) $(\mathrm{ng} / \mathrm{ml})$ : quantitative measurement of bioactive vit. D was carried out using sensitive competitive ELISA kits supplied from WKEA Med Supplies Corporation, China. The normal level of vitamin $\mathrm{D}$ is defined as a $25-\mathrm{OH}$-vitamin $\mathrm{D}$ 
concentration greater than $20 \mathrm{ng} / \mathrm{ml}(>50 \mathrm{nmol} /$ 1). Vitamin D insufficiency is defined as a 25 $\mathrm{OH}$-vitamin D concentration of $12-20 \mathrm{ng} / \mathrm{ml}$ (30-50 nmol/l). Vitamin D deficiency is defined as a $25-\mathrm{OH}$-vitamin D level less than $12 \mathrm{ng} / \mathrm{ml}$ $(<30 \mathrm{nmol} / \mathrm{l})[14]$.

\section{Statistical methods}

All statistical analyses were carried out using STATA/SE version 11.2 for Windows (STATA Corporation, College Station, TX). All results were expressed as mean and SD values for parametric data and median; Student's $t$-test was used for the mean values. The Mann-Whitney test for non-parametric quantitative data and chi-square test were used for comparing the categorical variables. Pearson correlation and Spearman were used for the correlation in parametric and non-parametric data, respectively. For all analyses, the level of significance was set at $P<0.05$.

\section{Results}

The study was conducted on 85 children divided into group I (beta-thalassemia major group) that included 55 children with BTM aged (5-17 years) with a mean age of $8.79 \pm 4.56$ years; they were $36(65 \%)$ male and 19 (35\%) female. Group II (control group) included 30 children age- and sex-matched, with a mean age of $8.02 \pm 4.65$ years, ranged 5-17 years; they were $20(66 \%)$ males and 10 (33\%) females. There was a statistically significant difference between the studied groups regarding weight, height, and BMI as they were statistically lower in the thalassemic group. As regards the family history of thalassemia, it was statistically higher in the thalassemic group $(P<0.001)$; however, there was no statistically significant difference as regards the age, sex, and consanguinity (Table 1)
The clinical manifestations of the thalassemic group were as follows: $96 \%$ had pallor, most of them (78\%) had mongoloid features, $86 \%$ had jaundice, 48 cases had hepatomegaly, 9 cases had splenectomy, and 36 cases had splenomegaly. None of the patients had $\mathrm{HBV}$ infection, but $12 \%$ had $\mathrm{HCV}$ infection. The mean age of the onset of first blood transfusion was $10.34 \pm 7.36$ months, and the mean rate of frequency of transfusion was $3.94 \pm 1.43$ weeks. As regards the type of iron-chelating agent, most of the patients (54.5\%) used deferasirox, followed by desferrioxamine with deferasirox (25.45\%), deferiprone (12.73\%), and desferrioxamine $(1.82 \%)$, and $5.45 \%$ have not received any iron-chelating agent.

Regarding hemoglobin, $\mathrm{MCV}$ and $\mathrm{MCH}$ were significantly statistically lower in the thalassemic group than in the control group. Ferritin and liver function tests (ALT, AST) were statistically significantly higher in the thalassemic group than in the control group; however, there were no statistically significant differences in $\mathrm{MCHC}$, WBCs, or platelets count (Table 2).

There was a statistically significant difference between the studied groups as regards the alkaline phosphatase levels and serum phosphorus as they were significantly higher in the thalassemic group than in the control group, but serum levels of calcium and 25-hydroxyvitamin D were much lower in the thalassemic group than in the control group; 22 cases (40\%) had insufficient vitamin D $(12-20 \mathrm{ng} / \mathrm{ml})$, and 5 cases $(9 \%)$ had deficient vitamin D $(<12 \mathrm{ng} / \mathrm{ml})$ (Table 3$)$.

There was no statistically significant correlation between the serum levels of 25-hydroxyvitamin D, calcium, phosphorus, and different variables among the thalassemic group (Table 4).

Table 1 Sociodemographic data and anthropometric measurements of the studied group

\begin{tabular}{|c|c|c|c|c|c|c|c|}
\hline \multirow[t]{2}{*}{ Variable } & & \multicolumn{2}{|c|}{ Thalassemic group (no. $=55$ ) } & \multicolumn{2}{|c|}{ Control group (no. $=30$ ) } & \multirow[t]{2}{*}{ Test } & \multirow[t]{2}{*}{$P$} \\
\hline & & Mean \pm SD & Range & Mean \pm SD & Range & & \\
\hline Age (years) & & $8.79 \pm 4.56$ & $5-17$ & $8.02 \pm 4.65$ & $5-17$ & $t=0.74$ & 0.46 \\
\hline Weight (kg) & & $20.78 \pm 12.44$ & $9-56$ & $28.73 \pm 14.87$ & $11-65$ & $Z=2.33$ & $0.02(S)$ \\
\hline Height (cm) & & $110.44 \pm 25.04$ & $75-150$ & $121.17 \pm 26.24$ & $77-170$ & $Z=1.20$ & $0.04(S)$ \\
\hline \multirow[t]{2}{*}{$\mathrm{BMI}\left(\mathrm{kg} / \mathrm{m}^{2}\right)$} & & $17.04 \pm 2.33$ & $13-24$ & $18.45 \pm 1.87$ & $16-23$ & $t=3.05$ & $0.003(S)$ \\
\hline & & No. & $\%$ & No. & $\%$ & Chi-square test & \\
\hline \multirow[t]{2}{*}{ Sex } & Female & 19 & 34.55 & 10 & 33.33 & 0.01 & 0.91 \\
\hline & Male & 36 & 65.45 & 20 & 66.67 & & \\
\hline \multirow[t]{2}{*}{ Family history of thalassemia } & No & 26 & 47.27 & 30 & 100.0 & 24.01 & $<0.001(\mathrm{HS})$ \\
\hline & Yes & 29 & 52.73 & 0 & 0.0 & & \\
\hline \multirow[t]{2}{*}{ Consanguinity } & Negative & 26 & 47.27 & 20 & 66.67 & 2.94 & 0.09 \\
\hline & Positive & 29 & 52.73 & 10 & 33.33 & & \\
\hline
\end{tabular}

$t$ Student $t$-test, $Z$ Mann-Whitney test, $B M I$ body mass index, $P$ probability (significant if $<0.05$ ) 
Table 2 Comparison between the studied groups regarding CBC parameters and liver function tests

\begin{tabular}{|c|c|c|c|c|c|c|}
\hline \multirow[t]{2}{*}{ Variable } & \multicolumn{2}{|c|}{ Thalassemic group (no. $=55$ ) } & \multicolumn{2}{|c|}{ Control group (no. $=30$ ) } & \multirow{2}{*}{$\begin{array}{l}\text { Mann- } \\
\text { Whitney } \\
\text { test }\end{array}$} & \multirow[t]{2}{*}{$P$} \\
\hline & Mean \pm SD & Range & Mean \pm SD & Range & & \\
\hline $\mathrm{HB}(\mathrm{g} / \mathrm{dl})$ & $8.14 \pm 1.09$ & $5.9-10.8$ & $11.77 \pm 0.56$ & $10.8-12.7$ & 7.59 & $<0.001(\mathrm{HS})$ \\
\hline $\mathrm{MCV}(\mathrm{fl})$ & $69.04 \pm 6.68$ & $52.3-63.3$ & $81.1 \pm 2.63$ & $76.9-87.3$ & 7.29 & $<0.001(\mathrm{HS})$ \\
\hline $\mathrm{MCH}(\mathrm{Pg})$ & $23.11 \pm 3.06$ & $16.5-24.5$ & $28.84 \pm 2.66$ & $23.4-35.3$ & $t=8.98$ & $<0.001(\mathrm{HS})$ \\
\hline $\mathrm{MCHC}(\mathrm{g} / \mathrm{dl})$ & $33.4 \pm 2.71$ & $27.4-30.9$ & $33.73 \pm 1.18$ & $31.3-36.3$ & 0.97 & 0.33 \\
\hline WBCs $\left(10^{3} / \mu l\right)$ & $9.02 \pm 4.5$ & $3.8-30.7$ & $8.14 \pm 2.39$ & $4.5-13.7$ & 0.32 & 0.75 \\
\hline Platelets $\left(10^{3} / \mu \mathrm{l}\right)$ & $339.36 \pm 177.3$ & $150-1262$ & $276.97 \pm 54.1$ & $175-365$ & 1.63 & 0.10 \\
\hline Ferritin $(\mathrm{ng} / \mathrm{ml})$ & $2739.71 \pm 2268.8$ & $310-11,051$ & $50.03 \pm 30.63$ & $15-150$ & 7.59 & $<0.001(H S)$ \\
\hline $\operatorname{ALT}(\mathrm{U} / \mathrm{l})$ & $63.27 \pm 44.31$ & $12-165$ & $19.57 \pm 4.85$ & $13-27$ & 6.11 & $<0.001(\mathrm{HS})$ \\
\hline AST (U/I) & $58.96 \pm 37.96$ & $11-184$ & $33.2 \pm 7.19$ & $23-45$ & 3.33 & $<0.001(\mathrm{HS})$ \\
\hline
\end{tabular}

$t$ Student $t$-test, $H B$ hemoglobin, $M C V$ mean corpuscular volume, $M C H$ mean corpuscular hemoglobin, $M C H C$ mean corpuscular hemoglobin concentration, WBCs white blood cells, AST aspartate aminotransferase, $A L T$ alanine aminotransferase, $H s$ highly significant

\section{Discussion}

Patients with thalassemia are subject to various complications such as impairment of development, endocrinopathies, and metabolic derangements. Proper circulation of vitamin D is crucial for ideal skeletal health and reduces the danger of fracture [6]. In the present study regarding weight, height, and body mass index (BMI), they were significantly lower in the thalassemic group. Similar findings were reported by other workers; Hashemi et al. [15] reported a low body mass index in $18.6 \%$ of their patients with beta-thalassemia major. Growth failure is prevalent in thalassemia patients as it is multifactorial, associated with chronic hypoxia owing to chronic anemia, chelation toxicity, low serum zinc concentration, hepatic iron overload with hepatic dysfunction, and iron-related endocrinopathies such as hypogonadism, hypothyroidism, and growth hormone deficiency [16]. However Hamed et al. [17] found that the mean BMI of their thalassemic patients was in the normal range.

In the current study, in beta-thalassemia cases, nearly all of them (96\%) had pallor, most of them (78\%) had mongoloid features, $86 \%$ have jaundice, 48 cases had hepatomegaly, 9 cases had splenectomy, and 36 cases had splenomegaly. This is in agreement with Behairy et al. [18] who found that the main presenting symptoms were a moderate-to-severe degree of pallor and hepatomegaly in all patients (100\%), jaundice in 95.7\%, and splenomegaly in $75.7 \%$ with splenectomy performed in $14.3 \%$ of cases; the incidence of mongoloid features was 81.4\%. Also, Salama et al. [19] found that thirty-two patients (40\%) suffered from jaundice and 34 (42.5\%) had thalassemic features.

In the current study, the mean serum level of $25-\mathrm{OH}-$ vitamin $\mathrm{D}$ was significantly much lower in our thalassemic patients than in controls; 22 cases $(40 \%)$ had insufficient vitamin D $(12-20 \mathrm{ng} / \mathrm{ml})$, and 5 cases $(9 \%)$ had deficient vitamin $\mathrm{D}(<12 \mathrm{ng} / \mathrm{ml})$. Vitamin D deficiency and insufficiency are reported to be high in thalassemic patients in many countries despite the presence of good sunshine and routine prescription of 400-1000 IU vitamin D per day. The risk of vitamin D deficiency in thalassemia and its relation to bone disease was high [20].

Vogiatzi et al. [16] reported that $12 \%$ of thalassemic patients were vitamin D-deficient, and $82 \%$ had

Table 3 Comparison between the thalassemic and control groups regarding Ca, Ph, vitamin D, and alkaline phosphatase

\begin{tabular}{|c|c|c|c|c|c|c|}
\hline \multirow[t]{2}{*}{ Variable } & \multicolumn{2}{|c|}{ Thalassemic group (no. $=55$ ) } & \multirow[b]{2}{*}{ Mean \pm SD } & \multirow[b]{2}{*}{ Range } & \multirow{2}{*}{$\begin{array}{l}\text { Mann- } \\
\text { Whitney } \\
\text { test }\end{array}$} & \multirow[t]{2}{*}{$P$} \\
\hline & Mean \pm SD & Range & & & & \\
\hline Calcium (mg/dl) & $5.61 \pm 0.87$ & $6.5-8.6$ & $9.71 \pm 0.34$ & $8.9-10.2$ & 1.25 & $<0.001(\mathrm{HS})$ \\
\hline Phosphorus (mg/dl) & $5.28 \pm 1.06$ & $3.1-7.6$ & $3.25 \pm 0.71$ & $3-5.5$ & $t=0.17$ & $<0.001(\mathrm{HS})$ \\
\hline Alkaline phosphatase (U/l) & $299.13 \pm 83.15$ & $168-582$ & $169.43 \pm 35.68$ & $85-310$ & 6.93 & $<0.001(H S)$ \\
\hline \multirow[t]{2}{*}{ Vit. D (ng/ml) } & $19.84 \pm 5.79$ & $9.5-31.35$ & $44.98 \pm 5.77$ & $36-57$ & 7.59 & $<0.001(\mathrm{HS})$ \\
\hline & No. & $\%$ & No. & $\%$ & & \\
\hline Normal vit. D & 28 & 50.90 & 30 & 100.00 & FET & $<0.001(\mathrm{HS})$ \\
\hline Insufficient vit. D & 22 & 40.00 & - & - & & \\
\hline Deficient vit. D & 5 & 9.09 & - & - & & \\
\hline
\end{tabular}


Table 4 Correlation between 25-OH-vitamin D, calcium, and phosphorus and studied variables among the thalassemic group

\begin{tabular}{|c|c|c|c|c|c|c|}
\hline \multirow[t]{2}{*}{ Variable $($ no. $=55)$} & \multicolumn{2}{|c|}{ 25-OH-vitamin D (ng/ml) } & \multicolumn{2}{|c|}{$\mathrm{Ca}(\mathrm{mg} / \mathrm{dl})$} & \multicolumn{2}{|c|}{$\mathrm{Ph}(\mathrm{mg} / \mathrm{dl})$} \\
\hline & Rho & $P$ & Rho & $P$ & Rho & $P$ \\
\hline 25-OH-vitamin D (ng/ml) & 1.00 & & & & & \\
\hline $\mathrm{Ca}(\mathrm{mg} / \mathrm{dl})$ & -0.19 & 0.16 & 1.00 & & & \\
\hline $\mathrm{Ph}(\mathrm{mg} / \mathrm{dl})$ & -0.21 & 0.11 & 0.24 & 0.08 & 1.00 & \\
\hline Age (years) & 0.07 & 0.60 & -0.20 & 0.14 & 0.05 & 0.73 \\
\hline Weight (kg) & 0.11 & 0.41 & -0.19 & 0.17 & 0.01 & 0.92 \\
\hline Height (cm) & 0.09 & 0.50 & -0.18 & 0.18 & -0.01 & 0.91 \\
\hline $\mathrm{BMI}\left(\mathrm{kg} / \mathrm{m}^{2}\right)$ & 0.05 & 0.73 & -0.01 & 0.92 & 0.002 & 0.99 \\
\hline Liver span (cm) & 0.16 & 0.24 & -0.17 & 0.22 & 0.06 & 0.63 \\
\hline Spleen length (cm) & -0.01 & 0.95 & -0.12 & 0.41 & -0.06 & 0.69 \\
\hline Age of start (months) & 0.05 & 0.69 & -0.12 & 0.37 & -0.05 & 0.71 \\
\hline Rate/week & 0.05 & 0.70 & 0.01 & 0.94 & 0.03 & 0.83 \\
\hline ALT (U/I) & 0.17 & 0.21 & 0.09 & 0.52 & -0.04 & 0.78 \\
\hline AST (U/I) & 0.11 & 0.42 & -0.05 & 0.74 & -0.12 & 0.36 \\
\hline $\mathrm{HB}(\mathrm{g} / \mathrm{dl})$ & 0.26 & 0.05 & 0.03 & 0.84 & -0.06 & 0.63 \\
\hline MCV (fl) & 0.03 & 0.83 & 0.01 & 0.94 & -0.20 & 0.14 \\
\hline $\mathrm{MCH}(\mathrm{Pg})$ & -0.04 & 0.75 & -0.03 & 0.85 & -0.06 & 0.65 \\
\hline MCHC (g/dl) & -0.005 & 0.97 & -0.10 & 0.46 & 0.13 & 0.36 \\
\hline WBCs $\left(10^{3} / \mu \mathrm{l}\right)$ & -0.11 & 0.42 & 0.18 & 0.18 & -0.20 & 0.15 \\
\hline Platelets $\left(10^{3} / \mu \mathrm{l}\right)$ & -0.02 & 0.87 & -0.03 & 0.84 & 0.15 & 0.27 \\
\hline Ferritin (ng/ml) & 0.06 & 0.65 & -0.008 & 0.95 & -0.05 & 0.71 \\
\hline Alkaline phosphatase & -0.004 & 0.97 & 0.25 & 0.07 & 0.13 & 0.33 \\
\hline
\end{tabular}

$A L T$ alanine transaminase, $A S T$ aspartate transaminase, $H B$ hemoglobin, $M C V$ mean corpuscular volume, $M C H$ mean corpuscular hemoglobin, $M C H C$ mean corpuscular hemoglobin concentration, WBCs white blood cells count

insufficient levels. Also, Agrawal et al. [21] found that the mean serum level of $25-\mathrm{OH}$-vitamin D was significantly lower in thalassemic patients than in controls, and $98 \%$ of thalassemic patients had vitamin D deficiency. Merchant et al. [22] found vitamin D deficiency in $62 \%$ Indian thalassemia major children and suggested that vitamin $\mathrm{D}$ deficiency was a nutritional deficiency and defective hydroxylation of vitamin $\mathrm{D}$ in the liver due to hemochromatosis as all children had high serum ferritin levels. Gombar et al. [1] found that the level of serum vitamin $\mathrm{D}$ was significantly low $(P$ value $<0.0001)$ in thalassemic children. Also, Hagag et al. [23] found that plasma 25-hydroxyvitamin D levels are found to be significantly lower in patients compared to controls.

The Middle Eastern and North African regions represent some of the highest rates of hypovitaminosis D worldwide. The prevalence of hypovitaminosis D in this region varies from 30 to $90 \%$, considering a desirable 25 $\mathrm{OH}$-vitamin D level of $20 \mathrm{ng} / \mathrm{ml}$ [24]. These deficient levels might be attributed to decreased sun exposure (conservative dressing culture and/or avoidance of exposure to hot sunny weather) [25]. Also, the food fortification policy is nearly absent in the majority of this region [24]. Concerning thalassemic patients, there are additional factors that might be implicated. Many authors, who have reported low vitamin D concentrations in thalassemia patients, attributed their results to hepatic dysfunction leading to defective hydroxylation of vitamin $\mathrm{D}$ and decreased serum levels [26].

In contrast to our results, Izzah et al. [27] found that vitamin $\mathrm{D}$ and phosphorus levels of patients do not differ significantly from healthy controls; however, they found that the mean calcium level was significantly lower in thalassemic patients.

In our study, beta-thalassemia patients had significantly higher serum phosphorus and alkaline phosphatase levels, and serum calcium was significantly lower than the control group. Results in these studies come in agreement with Karim et al. [2] who found that betathalassemia patients have shown significantly low serum Ca levels $(P<0.05)$ in comparison with the controls. Also, Hagag et al. [23] found that serum ionized calcium levels are significantly lower in the patient group and serum phosphorus and alkaline phosphatase levels are significantly higher. The same results by Saboor et al. [28] found that serum calcium level was low as compared with controls $(P<0.01)$. All patients had a high alkaline phosphatase level than in controls $(P<0.001)$. 
Levels of inorganic phosphorus were also high in patients than in controls. They explained their results by the presence of iron overload and hemosiderosis resulting in endocrinopathies (parathyroid gland). Chelation therapy in addition to cirrhotic changes due to hemosiderosis may also play a significant role in hypocalcemia. Sultan et al. [29] found that hypocalcemia and hyperphosphatemia were seen in $66.6 \%$ and $19.4 \%$, respectively, while $25-\mathrm{OH}$-vitamin D deficiency was present in $72.2 \%$ of thalassemic patients.

In contrast to our results, Salama et al. [30] found that serum phosphorus level was significantly higher in their thalassemic patients than in the controls but no alteration in calcium level in $\beta$-thalassemia major patients as compared with controls; this may reflect hypoparathyroidism.

\section{Conclusion}

Vitamin D insufficiency was common in children with beta-thalassemia major. Also, children with betathalassemia major had low BMI and metabolic abnormality in the form of low serum calcium and higher serum phosphorus and alkaline phosphatase. The presence of these abnormalities may be due to iron overload and poor nutritional support and they need frequent monitoring for early detection and management.

\section{Acknowledgements}

Not applicable

\section{Authors' contributions}

G A contributed to the design and implementation of the research, aided in choosing the patients appropriate for the study and data collection, and read and approved the final manuscript. O B contributed to the design and implementation of the research, aided in choosing the patients and helped shape the research, supervised the findings of this work, discussed the results, and read and approved the final manuscript. K A was involved in planning and supervising the findings of this work, discussed the results, and read and approved the final manuscript. D A performed the laboratory work, discussed the results, and read and approved the final manuscript. T H aided in choosing the patients appropriate for the study and data collection, aided in interpreting the results, and read and approved the final manuscript.

\section{Funding}

No funding and no grants.

\section{Availability of data and materials}

Not applicable

\section{Declarations}

\section{Ethics approval and consent to participate}

The current study was approved by the Medical Research Ethical Committee of the Faculty of Medicine, Benha University. All subjects were informed about the procedures and the aim of the study, and informed written consent was obtained from the parents or caregivers of enrolled children. The committee's reference number is not available

\section{Consent for publication}

Not applicable

\section{Competing interests}

The authors declare that they have no competing interests.

\section{Author details}

'Pediatrics Department, Faculty of Medicine, Benha University, Benha, Egypt. ${ }^{2}$ Consultant of Pediatric Hematology, Faculty of Medicine, Cairo University, Cairo, Egypt. ${ }^{3}$ Clinical Pathology Department, Faculty of Medicine, Benha University, Benha, Egypt. ${ }^{4}$ M.B.B.CH, Faculty of Medicine- Benha University, Benha, Egypt.

Received: 13 June 2019 Accepted: 2 August 2021

Published online: 01 September 2021

\section{References}

1. Gombar S, Parihar K, Choudhary M (2018) Comparative study of serum ferritin and vitamin $\mathrm{D}$ in thalassemia patients with healthy controls. Int J Res Med Sci 6(2):693-695. https://doi.org/10.18203/2320-6012.ijrms20180322

2. Karim MF, Ismail M, Hasan AM, Shekhar HU (2016) Hematological and biochemical status of beta-thalassemia major patients in Bangladesh: a comparative analysis. Int J Hematol Oncol Stem Cell Res 10(1):7-12

3. El-Shanshory M, Hagag A, Shebl S, Badria I, Abd Elhameed A, Abd El-Bar E et al (2014) Spectrum of beta globin gene mutations in Egyptian children with $\beta$-thalassemia. Mediterranean Journal of Hematology and Infectious Diseases 6(1):e2014071. https://doi.org/10.4084/mjhid.2014.071

4. Shawky RM, Kamal TM (2012) Thalassemia intermedia: an overview. Egypt J Med Hum Genet 13(3):245-255. https://doi.org/10.1016/j.ejmhg.2012.03.006

5. Wong P, Fuller PJ, Gillespie MT, Milat F (2016) Bone disease in thalassemia: a molecular and clinical overview. Endocr Rev 37(4):320-346. https://doi.org/1 0.1210/er.2015-1105

6. El-Nashar M, Mortagy AK, El-Beblawy NM, El-Gohary E, Kamel IM, Rashad M, Mouharam WA (2017) Parathyroid hormone in pediatric patients with betathalassemia major and its relation to bone mineral density; a case-control study. The Egyptian Journal of Medical Human Genetics 18(1):75-78. https:// doi.org/10.1016/j.ejmhg.2016.03.004

7. Mehdi Khani B, Eslami A, Qorbani M, Azarkeivan A, Mohammadi Z, Khashayar P, Keshtkar A (2015) Knowledge, attitude, and preventive practice of major thalassemia patients regarding the importance of calcium and vitamin D. Journal of Applied Hematology 6(1)

8. Xu Z, Fan C, Zhao X, Tao H (2016) Treatment of osteoporosis with eldecalcitol, a new vitamin $D$ analog: a comprehensive review and metaanalysis of randomized clinical trials. Drug Des Devel Ther 10:509-517

9. Chatterjee R, Bajoria R (2009) Osteopenia-osteoporosis syndrome in patients with thalassemia: understanding of type of bone disease and response to treatment. Hemoglobin 33(1):136-S138

10. Giardina PJ, Forget BG (2008) Thalassemia syndromes. In: Hoffman R, Benz EJ, Shattil SS, et al., eds. Hematology: basic principles and practice. 5th ed. Philadelphia, Pa: Elsevier Churchill Livingstone chap 41.

11. WHO Anthro (version 3.2.2, 2011). Software for assessing growth and development of the world's children. Geneva: WHO, 2011. http://www.who. int/childgrowth/software/en/.

12. Hammer LD, Kraemer HC, Wilson DM, Ritter PL, Dornbusch SM (1991) Standardized percentile curves of body mass index for children and adolescents. Am J Dis Child 145(3):259-263. https://doi.org/10.1001/a rchpedi.1991.02160030027015

13. England JM, Rowan RM, van Assendelft OW, Coulter WH, Groner W, Jones AR, Koepke JA, Lewis SM, Shinton NK, Thom R (1984) Protocol for evaluation of automated blood cell counters. International Committee for Standardization in Hematology (ICSH). Clin Lab Haematol 6(1):69-84. https:// doi.org/10.1111/j.1365-2257.1984.tb00528.x

14. Munns CF, Shaw N, Kiely M, Specker BL, Thacher TD, Ozono K, Michigami T, Tiosano D, Mughal MZ, Mäkitie O, Ramos-Abad L, Ward L, DiMeglio LA, Atapattu N, Cassinelli H, Braegger C, Pettifor JM, Seth A, Idris HW, Bhatia V, Fu J, Goldberg G, Sävendahl L, Khadgawat R, Pludowski P, Maddock J, Hyppönen E, Oduwole A, Frew E, Aguiar M, Tulchinsky T, Butler G, Högler W (2016) Global consensus recommendations on prevention and management of nutritional rickets. J Clin Endocrinol Metab 101(2):394-415. https://doi.org/10.1210/jc.2015-2175

15. Hashemi A, Ghilian R, Golestan M et al (2011) The study of growth in thalassemic patients and its correlation with serum ferritin level. IJPHO 1(4): $147-151$

16. Vogiatzi MG, Macklin EA, Trachtenberg FL, Fung EB, Cheung AM, Vichinsky E, Olivieri N, Kirby M, Kwiatkowski JL, Cunningham M, Holm IA, Fleisher M, Grady RW, Peterson CM, Giardina PJ, for the Thalassemia Clinical Research Network (2009) Differences in the prevalence of growth, endocrine and 
vitamin $\mathrm{D}$ abnormalities among the various thalassemia syndromes in North America. Br J Haematol 146(5):546-556. https://doi.org/10.1111/j.1365-2141.2 009.07793.x

17. Hamed EA, El-Melegy NT (2010) Renal functions in pediatric patients with beta-thalassemia major: relation to chelation therapy: original prospective study. Ital J Pediatr 36(1):39. https://doi.org/10.1186/1824-7288-36-39

18. Behairy OG, ER AA, Abed NT, Abdel Haiea OM, Zakaria RM, RI AE et al (2017) Role of serum cystatin-C and beta-2 microglobulin as early markers of renal dysfunction in children with beta-thalassemia major. Int I Nephrol Renov Dis 10:261-268

19. Salama KM, Ibrahim OM, Kaddah AM, Boseila S, Ismail LA, Hamid MMA (2015) Liver enzymes in children with beta-thalassemia major: correlation with iron overload and viral hepatitis. Open Access Macedonian Journal of Medical Sciences 3(2):287-292. https://doi.org/10.3889/oamjms.2015.059

20. Soliman A, De Sanctis V, Yassin M (2013) Vitamin D status in thalassemia major: an update. Mediterr J Hematol Infect Dis 5(1):e2013057. https://doi. org/10.4084/mjhid.2013.057

21. Agrawal A, Garg M, Singh J, Mathur P, Khan K (2016) Comparative study of 25 hydroxyvitamin $\mathrm{D}$ levels in patients of thalassemia and healthy children. International Journal of Pediatric Research 3(9):652-656. https://doi.org/10.1 7511/ijpr.2016.109.04

22. Merchant R, Udani A, Puri V, D'cruz V, Patkar D, Karkera A (2010) Evaluation of osteopathy in thalassemia by bone mineral densitometry and biochemical indices. The Indian Journal of Pediatrics 77(9):987-991. https:// doi.org/10.1007/s12098-010-0158-2

23. Hagag AA, El-Shanshory MR, Abo El-Enein AM (2015) Parathyroid function in children with beta-thalassemia and correlation with iron load. Advances in Pediatric Research 2(3):98-105

24. Bassil D, Rahme M, Hoteit M, Fuleihan GE (2013) Hypovitaminosis D in the Middle East and North Africa. Dermatoendocrinol 1 5(2):274-298. https:// doi.org/10.4161/derm.25111

25. Allam NT, El-Wakda MM, El-Abdb DM, Dorgham DA (2014) Prevalence of vitamin D deficiency in Egyptian rheumatoid arthritis patients: correlation with disease activity, functional disability, and bone mineral density. Egyptian Rheumatology \& Rehabilitation 41(3):92-97. https://doi.org/10.41 03/1110-161X.140521

26. Fahim FM, Saad K, Askar EA, Nasr Eldin E, Thabet AF (2013) Growth parameters and vitamin $D$ status in children with thalassemia major in Upper Egypt. Int J Hematol Oncol Stem Cell Res 7(4):10-14

27. Izzah AZ, Rofinda ZD, Arbi F (2017) Vitamin D and parathyroid hormone levels and their relation to serum ferritin levels in children with thalassemia major: One-Center Study in Western Indonesia. Journal of Advances in Medical and Pharmaceutical Sciences 15(1):1-5. https://doi.org/10.9734/JA MPS/2017/35473

28. Saboor M, Qudsia F, Qamar K, Moinuddin M (2014) Levels of calcium, corrected calcium, alkaline phosphatase and inorganic phosphorus in patients' serum with $\beta$-thalassemia major on subcutaneous deferoxamine. J Hematol Thromb Dis 2(2):130

29. Sultan S, Irfan SM, Ahmed SI (2016) Biochemical markers of bone turnover in patients with $\beta$-thalassemia major: a single-center study from southern Pakistan. Adv Hematol 2016:5437609

30. Salama OS, Al-Tonbary YA, Shahin RR, Eldeen OA (2006) Unbalanced bone turnover in children with beta-thalassemia. Hematology 11(3):197-202. https://doi.org/10.1080/10245330600702851

\section{Publisher's Note}

Springer Nature remains neutral with regard to jurisdictional claims in published maps and institutional affiliations.

\section{Submit your manuscript to a SpringerOpen ${ }^{\circ}$ journal and benefit from:}

- Convenient online submission

- Rigorous peer review

- Open access: articles freely available online

- High visibility within the field

- Retaining the copyright to your article

Submit your next manuscript at $\boldsymbol{\nabla}$ springeropen.com 